\title{
Yield and Yield Component Responses of Vegetable Crops to Farmyard Manure Rates in the Presence of Inorganic Fertilizer ${ }^{1}$
}

\author{
J. E. Asiegbu and J. O. Uzo ${ }^{2}$
}

\section{ABSTRACT}

Results indicated the need for use of organic manures even when a high rate of NPK fertilizer was applied. Farmyard manure (FYM) benefitted fruit set in egg plant and generally enhanced size characters in both onion and eggplants. FYM helped to increase the proportion of grade one onions, especially at relatively high plant densities. Increasing plant density increased yield per hectare, but decreased productivity per plant. Yield increase per hectare was therefore largely dependent on number of plants contributing to yield and, in eggplant, also on the number of fruits set per plant.

\section{INTRODUCTION}

Currently there is an accelerated reduction in fallow periods due to pressure on farm lands in Nigeria. This has led to an increase in the use of inorganic fertilizers by the local farmers, with a concomitant reduction in the use of organic manures. Work in the Faculty of Agriculture at Nsukka, Nigeria, has always shown the need for organic manure applications for maximum response to inorganic fertilizers in vegetable crops. The local eggplant used in this work is a promising cultivar produced in the faculty, but relatively little is known about its spacing and manurial requirements. Two experiments were therefore conducted to determine the response to varying rates of FYM by eggplant and onion at varying plant densities when NPK fertilizer was also applied at standard rates for vegetable crops.

\section{MATERIALS AND METHODS}

Two experiments were conducted on a ferrallitic sandy clay loam soil of the humid tropics at Nsukka between June and November, 1981. Initial soil characteristics determined included $\mathrm{pH}, 5.8$ (1:2, 5, soil: water) available $\mathrm{Ca}(0.064 \%), \mathrm{Mg}$ (trace) and $\mathrm{C}(1.97 \%)$. The mean monthly rainfall was $207.9 \mathrm{~mm}$ and the maximum air temperature varied between 28 and $30^{\circ} \mathrm{C}$, while the minimum varied between 19 and $21^{\circ} \mathrm{C}$.

\section{EXPERIMENT 1}

This experiment was an eggplant factorial experiment with four population densities and four FYM rates. Plant densities (D) were $D_{1}, 17$,

${ }^{1}$ Manuscript submitted to Editorial Board October 18, 1982.

${ }^{2}$ Department of Crop Science, University of Nigeria, Nsukka, Nigeria. 
$939 ; \mathrm{D}_{2}, 26,909 ; \mathrm{D}_{3}, 36,878$; and $\mathrm{D}_{4}, 53,818$ plants per hectare. The FYM rates were $0,5,10$ and 20 tons per hectare. There were three replications in a complete block design. Seeds were sown in the nursery June, 22, 1982 and transplanted July 30 at the four-leaf stage. NPK fertilizer was applied at the rate of $370 \mathrm{~kg} \mathrm{~N}, 196.5 \mathrm{~kg} \mathrm{P}$ and $373 \mathrm{~kg} \mathrm{~K}$ per hectare, considered to be ample enough. Plots were weeded five times. Vetox-83 was effective in controlling insect pests. Fruit harvest started September 22 and continued at a weekly interval till November 10.

\section{EXPERIMENT 2}

This experiment was with onion. The treatments consisted of the same FYM rates used in experiment 1; plant populations were at the following densities: $\mathrm{D}_{1}, 222,222 ; \mathrm{D}_{2}, 266,667 ; \mathrm{D}_{3}, 333,333$; and $\mathrm{D}_{4}, 444,444$ plants per hectare. There were also three replications in complete blocks. "Nsukka red" onion seeds were sown in the nursery June 16 and the seedlings were transplanted 51 days later. NPK fertilizer was applied to all plots at the same rate as in experiment 1 , and plots were weeded when necessary. Total bulb harvest was done November 10, and grading of onion bulbs was on the basis of diameter measured with Vernier callipers. There were four grades as follows: grade one, $6.4 \mathrm{~cm}$; grade two, 4.5-6.4 $\mathrm{cm}$; grade three, $2.5-4.4 \mathrm{~cm}$, and grade four, $2.5 \mathrm{~cm}$. Those in grade four were considered unmarketable. Statistical analyses of data were according to the methods of Steel and Torrie (8) for factorial experiments.

\section{RESULTS}

\section{EXPERIMENT 1}

At 51 days from planting, increased FYM and plant density rates progressively decreased the number of branches produced per eggplant (table 1). There was no statistically significant interaction for manure and plant density. High manure rates had an opposite effect, compared with high plant densities, by increasing leaf number per plant. The number of fruits produced per plant significantly increased with all FYM increments, but was depressed with high plant density. The depressant effect of high density was low with high manure rates (table 2). Fruit yield $(\mathrm{kg} / \mathrm{ha})$ was significantly increased $(\mathrm{P}<0.05)$ by increased application of FYM, although this proportion of $20 \mathrm{t} / \mathrm{ha}$ of FYM gave higher yield than that of $10 \mathrm{t} / \mathrm{ha}$ of FYM, on the average. Increased plant density consistently increased fruit yield $(\mathrm{P}<0.05)$. FYM $\times$ plant density interaction showed that except for the lowest plant density, there were no benefits in applying FYM beyond the rate of $10 \mathrm{t} / \mathrm{ha}$ under the conditions of the experiment. The average fruit weight rose on the second picking date to $126.7 \mathrm{~g}$ by $16.7 \%$, and subsequently remained fairly 
TABLE 1.-Number of branches (51 DAP ${ }^{1}$ ) and leaves (56 DAP) per eggplant

\begin{tabular}{|c|c|c|c|c|c|c|c|c|c|c|}
\hline \multirow{3}{*}{$\begin{array}{c}\text { Plant } \\
\text { density }\end{array}$} & \multicolumn{5}{|c|}{ No. of branches } & \multicolumn{5}{|c|}{ No. of leaves } \\
\hline & \multicolumn{5}{|c|}{ Farmyard manure (t/ha.) } & \multicolumn{5}{|c|}{ Farmyard manure (t/ha.) } \\
\hline & 0 & 5 & 10 & 20 & Mean $^{2}$ & 0 & 5 & 10 & 20 & Mean $^{2}$ \\
\hline $\mathrm{D}_{1}$ & $5.8^{4}$ & 5.0 & 4.6 & 3.7 & 4.8 & 102.7 & 129.4 & 159.7 & 187.9 & 144.9 \\
\hline $\mathrm{D}_{2}$ & 5.0 & 4.8 & 4.5 & 3.5 & 4.5 & 102.2 & 124.7 & 147.5 & 171.4 & 136.2 \\
\hline $\mathrm{D}_{3}$ & 4.7 & 3.8 & 3.3 & 2.9 & 3.7 & 89.7 & 96.5 & 127.2 & 141.5 & 113.7 \\
\hline $\mathrm{D}_{4}$ & 4.4 & 3.6 & 3.3 & 2.5 & 3.4 & 78.8 & 91.9 & 117.8 & 124.8 & 103.3 \\
\hline Mean $^{3}$ & 4.9 & 4.3 & 3.9 & 3.2 & 4.1 & 93.1 & 110.6 & 138.1 & 156.3 & 124.5 \\
\hline
\end{tabular}


TABLE 2.-Treatment effects on the fruit yields of eggplant

\begin{tabular}{|c|c|c|c|c|c|c|c|c|c|c|}
\hline \multirow{3}{*}{$\begin{array}{c}\text { Plant } \\
\text { density }\end{array}$} & \multicolumn{5}{|c|}{ No. of fruits/plant } & \multicolumn{5}{|c|}{ Fresh weight of fruit (t/ha.) } \\
\hline & \multicolumn{5}{|c|}{ Farmyard manure (t/ha.) } & \multicolumn{5}{|c|}{ Farmyard manure (t/ha.) } \\
\hline & 0 & 5 & 10 & 20 & Mean $^{1}$ & 0 & 5 & 10 & 20 & Mean $^{1}$ \\
\hline $\mathrm{D}_{1}$ & $17.0^{3}$ & 21.2 & 32.1 & 34.1 & 26.1 & 40.4 & 52.3 & 65.8 & 74.7 & 58.3 \\
\hline $\mathrm{D}_{2}$ & 15.8 & 17.8 & 23.9 & 28.8 & 21.6 & 62.8 & 83.7 & 97.2 & 101.6 & 86.3 \\
\hline $\mathrm{D}_{3}$ & 13.8 & 18.0 & 20.3 & 32.9 & 21.3 & 73.2 & 103.1 & 125.6 & 127.1 & 107.3 \\
\hline $\mathrm{D}_{4}$ & 11.3 & 12.9 & 17.4 & 24.6 & 16.6 & 80.7 & 119.6 & 161.4 & 145.0 & 126.7 \\
\hline Mean $^{2}$ & 14.5 & 17.5 & 23.4 & 30.1 & 21.4 & 64.3 & 89.7 & 112.1 & 112.1 & 94.7 \\
\hline
\end{tabular}

${ }^{1}$ Plant density means: S.e. diff. $= \pm 0.91^{* 4} \pm 1.97^{*}$.

${ }^{2}$ Manure means: S.e. diff. $= \pm 0.91^{*} ; \pm 1.97^{*}$.

${ }^{3}$ Plant density $\times$ manure means: S.e. diff. $= \pm 1.83^{*} ; \pm 3.93^{*}$.

${ }^{4}$ Significant at $\mathrm{P}=0.05$. 
constant for the following three picking dates (fig. 1). A sharp fall in average fruit weight occurred during the fifth picking and remained mostly constant subsequently. Fruit diameter was $7.6 \mathrm{~cm}$ on the average in the first four pickings, but fell to an average of $6.5 \mathrm{~cm}$ in the last four pickings.

\section{EXPERIMENT 2}

The effects of plant density and FYM on leaf number per onion plant were similar to the results obtained in experiment 1 with eggplant (table
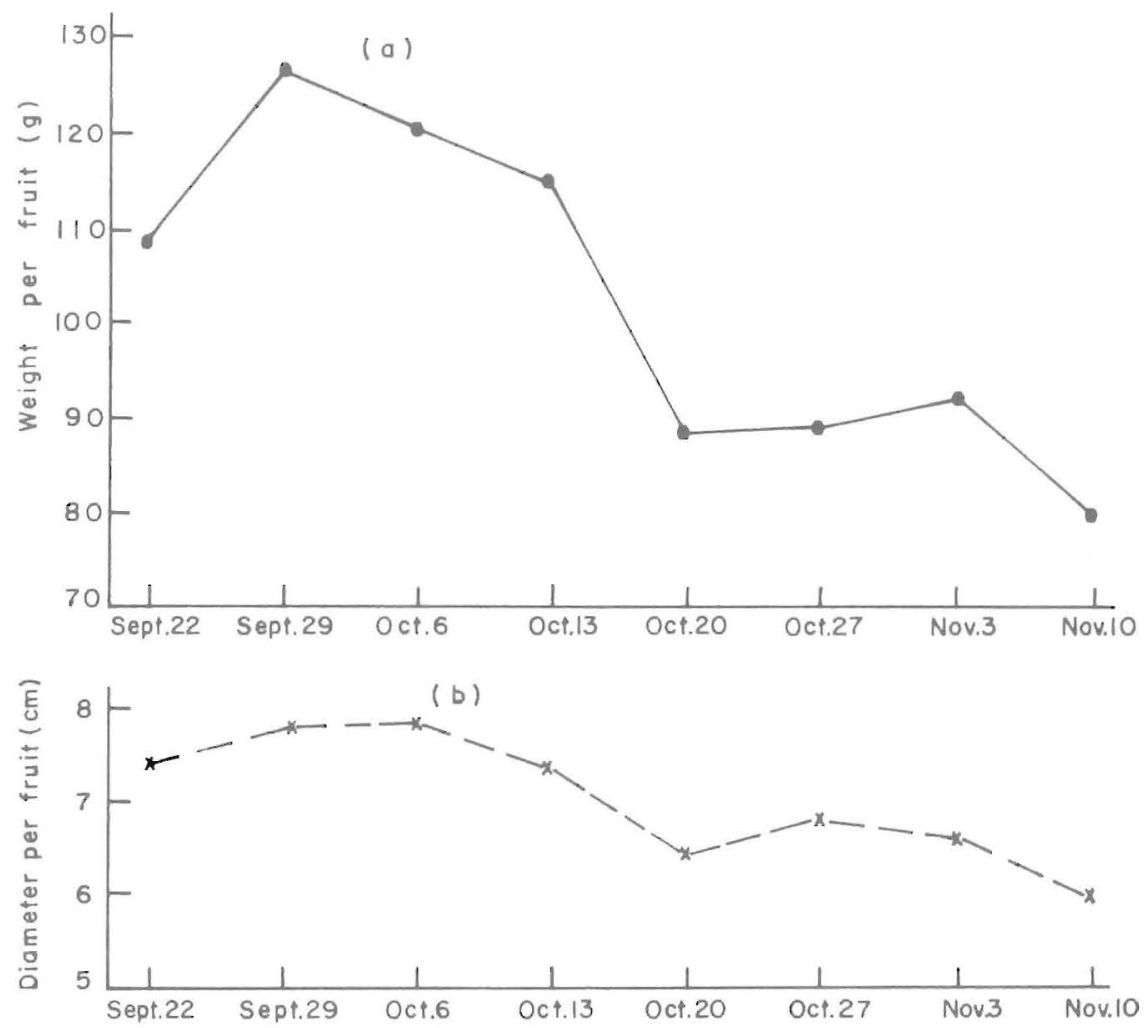

FIG. 1.-Changes in (a) fruit weight, and (b) fruit diameter in eggplant at different harvest dates.

3). Total leaf area per onion plant followed much the same trends as number of leaves per plant. FYM application significantly increased onion bulb diameter; at the 20 t/ha FYM rate, the increase was $81 \%$ compared with no FYM application (table 4). Bulb diameter decreased with plant population but the percentage decrease was less with high 
TABLE 3.-Leaf number and leaf area $\left(\mathrm{cm}^{2}\right)$ per onion plant at 3-month-old stage

\begin{tabular}{|c|c|c|c|c|c|c|c|c|c|c|}
\hline \multirow{3}{*}{$\begin{array}{c}\text { Plant } \\
\text { density }\end{array}$} & \multicolumn{5}{|c|}{ Leaf number per plant } & \multicolumn{5}{|c|}{ Leaf area per plant } \\
\hline & \multicolumn{5}{|c|}{ Farmyard manure (t/ha.) } & \multicolumn{5}{|c|}{ Farmyard manure ( $\mathrm{t} / \mathrm{ha}$.) } \\
\hline & 0 & 5 & 10 & 20 & Mean $^{1}$ & 0 & 5 & 10 & 20 & Mean $^{1}$ \\
\hline $\mathrm{D}_{1}$ & $10.0^{3}$ & 11.0 & 10.7 & 12.0 & 10.9 & 43.7 & 52.6 & 60.6 & 74.8 & 57.9 \\
\hline $\mathrm{D}_{2}$ & 9.3 & 10.3 & 11.0 & 11.3 & 10.5 & 32.7 & 51.4 & 57.9 & 68.4 & 52.6 \\
\hline $\mathrm{D}_{3}$ & 7.3 & 8.0 & 10.0 & 9.7 & 8.8 & 26.3 & 45.8 & 52.0 & 60.5 & 46.2 \\
\hline $\mathrm{D}_{4}$ & 5.0 & 7.7 & 9.0 & 10.7 & 8.1 & 16.4 & 29.9 & 46.5 & 57.3 & 37.3 \\
\hline Mean $^{2}$ & 7.9 & 9.3 & 10.2 & 10.9 & 9.6 & 29.8 & 44.9 & 54.2 & 65.3 & 48.6 \\
\hline
\end{tabular}

${ }^{1}$ Plant density means: S.e. diff, $= \pm 0.60^{* 4} ; \pm 1.06^{*}$.

${ }^{2}$ Manure means: S.e. diff. $= \pm 0.60 ; \pm 1.06^{*}$.

${ }^{3}$ Plant density manure means: S.e. diff. $= \pm 1.20 ; \pm 2.11^{*}$.

${ }^{4}$ Significant at $\mathrm{P}=0.05$. 
TABLE 4.-Onion bulb diameter $(\mathrm{cm})$ and total bulb yield $(\mathrm{t} / \mathrm{ha}$.)

\begin{tabular}{|c|c|c|c|c|c|c|c|c|c|c|}
\hline \multirow{3}{*}{$\begin{array}{c}\text { Plant } \\
\text { density }\end{array}$} & \multicolumn{5}{|c|}{ Bulb diameter $(\mathrm{cm})$} & \multicolumn{5}{|c|}{ Bulb fresh yield (t/ha.) } \\
\hline & \multicolumn{5}{|c|}{ Farmyard manure (t/ha.) } & \multicolumn{5}{|c|}{ Farmyard manure (t/ha.) } \\
\hline & 0 & 5 & 10 & 20 & Mean $^{1}$ & 0 & 5 & 10 & 20 & Mean $^{1}$ \\
\hline $\mathrm{D}_{1}$ & $5.3^{3}$ & 6.4 & 7.3 & 9.7 & 7.2 & 2.4 & 3.3 & 6.4 & 7.5 & 4.9 \\
\hline $\mathrm{D}_{2}$ & 4.9 & 6.0 & 7.2 & 8.3 & 6.6 & 2.4 & 5.8 & 7.7 & 8.7 & 6.2 \\
\hline $\mathrm{D}_{3}$ & 4.1 & 4.9 & 6.6 & 7.4 & 5.8 & 1.8 & 6.4 & 8.9 & 10.3 & 6.9 \\
\hline $\mathrm{D}_{4}$ & 3.1 & 4.0 & 5.0 & 6.4 & 4.7 & 1.2 & 7.7 & 9.7 & 11.7 & 7.6 \\
\hline Mean $^{2}$ & 4.4 & 5.3 & 6.5 & 8.0 & 6.1 & 2.0 & 5.8 & 8.2 & 9.6 & 6.4 \\
\hline
\end{tabular}

${ }^{1}$ Plant density means: S.e. diff. $= \pm 0.83^{* 4} ; \pm 0.32^{*}$.

${ }^{2}$ Manure means: S.e. diff. $\pm 0.83^{*} ; \pm 0.32^{*}$.

${ }^{3}$ Plant density $\times$ manure means: S.e. diff. $\pm 0.63^{*}$; NS ${ }^{4}$

$4 *=$ Significant at $\mathrm{P}=0.05 ; \mathrm{NS}=$ Not significant. 
rate of FYM than with low rate or none. Compared with no FYM application onion yield more than doubled or increased nearly five-fold when FYM was applied at 5 and $20 \mathrm{t} / \mathrm{ha}$, respectively. Over all, there were gradual increases in bulb yield ( $\mathrm{t} / \mathrm{ha}$ ) with increasing plant density, although significant yield reduction occurred with high plant densities when no FYM was applied. The percentage of grade one onions was rather low with no FYM and with high plant densities, and increased very significantly with increasing rates of FYM (table 5).

TABLE 5.-Percentage of total number of onion bulbs in grade one

\begin{tabular}{cccccc}
\hline $\begin{array}{c}\text { Plant } \\
\text { density }\end{array}$ & 0 & 5 & 10 & 20 & Mean $^{2}$ \\
$\mathrm{D}_{1}$ & $27.3^{3}$ & 65.0 & 77.0 & 86.0 & 63.8 \\
$\mathrm{D}_{2}$ & 27.7 & 53.0 & 73.3 & 81.0 & 58.8 \\
$\mathrm{D}_{3}$ & 18.0 & 42.0 & 57.7 & 70.7 & 47.1 \\
$\mathrm{D}_{4}$ & 8.0 & 32.0 & 43.3 & 55.7 & 34.8 \\
Mean $^{2}$ & 20.3 & 48.0 & 62.8 & 73.4 & 51.2 \\
\hline
\end{tabular}

${ }^{1}$ Plant density means: S.e. diff. $= \pm 3.46^{* 4}$.

${ }^{2}$ Manure means: S.e. diff, $= \pm 3.46^{*}$.

${ }^{3}$ Plant density $\times$ manure mean: S.e. diff. $=$ N.S.

${ }^{4}$ Significant at $\mathrm{P}=0.05$.

\section{DISCUSSION}

The very high responses to FYM by both crops were of interest and confirmed the view by Owen (7) and Uzo (10) that the use of organic manure enhances benefits from the application of inorganic fertilizers. Haworth and Cleaver (5) also found that in winter lettuce, plots receiving FYM plus inorganic fertilizer yielded twice as much as those that received inorganic fertilizer alone. The results by Bache and Heathcote (2) showed that the use of cattle FYM significantly increased soil C, N, pH, C.E.C. and exchangeable $\mathrm{Ca}, \mathrm{Mg}$, and $\mathrm{K}$ and decreased soluble $\mathrm{Al}$ and $\mathrm{Mn}$ which are very important factors in understanding the general effects of FYM in the present experiment. In addition to supplying nutrient elements, FYM will have overall enhanced the general conditions conducive to good crop growth. Stephen (9) has also noted that FYM was more effective than inorganic N.P.K. and $\mathrm{Mg}$ fertilizers in sustaining yield responses by different crops.

That onion appeared to respond more to FYM than eggplant was largely attributable to the fact that the natural soil for onion growth is "muck" soils. In Nigeria, onion is mostly grown in the fadama or river banks which annually receive alluvial deposits at flood season and which are very high in organic matter and plant nutrients. It was therefore 
demonstrated that with adequate organic manure application and good management, yields similar to those obtained in the fadama can also be obtained in the sandy clay loam soils of Nsukka. The nature of the onion plant with comparatively reduced aerial competition among plants will have also helped in sustaining response to high manure rates since competition for nutrient would be largely underground.

The effect of high plant densities in decreasing both number of branches (in eggplant) and productivity per plant (in onion and eggplant), but increasing total yield per hectare generally agreed with the literature on various crops $(4,1,6)$. Blum (4) working with Vicia sativa explained that increased yield with reduced inter-row spacing was due to higher number of plants and stems per unit area, although seed set per plant was better with wide-spaced rows than with reduced inter-row spacing. Increased yield per hectare with increasing densities in our experiment was similarly due to greater number of plants resulting in greater number of bulbs in onion and fruit in eggplant per unit area of ground. Abdella (1) also got higher yields of seed per unit area with closer spacing essentially on account of greater plant number contributing to yield per unit area of ground.

Onion bulb sizes are adversely affected by high plant population, especially where large size bulbs are more acceptable. Bleasdale (3) found that increasing plant density increased total yield of onion bulb until an optimum was reached and that at the optimum density for total yield, the bulbs were too small for normal market purposes. This view of effect of plant population on onion bulb size appeared largely confirmed under no or low FYM rate in this experiment. However, with high manure rates, reasonable proportions of grade one bulbs could still be produced under relatively high population densities.

In eggplant, increased yield per hectare with FYM application came essentially from greater fruit set per plant and presumably also from greater size per fruit. In onion, yield increases with FYM rates were due to greater size of bulbs.

With increasing trend in the use of inorganic fertilizer by local farmers there has been a tendency for them to underestimate the importance of organic manures. The need for use of organic manures even when N.P.K. fertilizer is applied has been demonstrated. It was also concluded that in the study of manure rates, incorporation of plant population densities would yield more comprehensive information necessary for fuller exploitation of the manure applied.

\section{RESUMEN}

Los resultados indican que es necesario usar estiércoles aun cuando se apliquen grandes cantidades de abonos íntegros (N-P-K). El estiércol de 
corral (FYM) mejoró el nacimiento de las frutas en la berenjena y generalmente aumentó el tamaño tanto de las berenjenas como el de las cebollas. El estiércol aumentó la proporción de cebollas de la más alta calidad, principalmente en densidades de plantación relativamente altas. El aumento en densidad aumentó el rendimiento por hectárea, pero disminuyó la productividad por planta. El aumento en rendimiento por hectárea de la berenjena dependió en gran medida del número de plantas y también del número de frutas por planta.

\section{LITERATURE CITED}

1. Abdalla, A. A., 1969. Effects of planting date and spacing on the yields of onion seed under hot arid conditions in the Sudan, Exp. Agric. 5: 147-49.

2. Bache, B. M. and Heathcote, R. G., 1969. Long-term effects of fertilizers and manure on soil and leaves of cotton in Nigeria, Exp. Agric. 5: 241-47.

3. Bleasdale, J. K. A., 1966. The effects of plant spacing on the yield of bulb onions. (Allum cepa L.) grown from seed, J. Hort. Sci. 41: 145-53.

4. Blum, A., 1966. The influence of plant density on the morphological characters and seed production of common vetch (Vicia sativa), Exp. Agric. 2: 61-7.

5. Haworth, F. and Cleaver, T. J., 1967. The effects of different manurial treatments on the yield and mineral composition of winter lettuce, J. Hort. Sci. 42: 23-9.

6. Ojehomon, O. O. and Bamiduro, T. A., 1972. The effects of plant density and pattern of plant arrangement on cowpea (Vigna unguiculata L.) using parallel row systematic spacing design, Niger, Agric. J. 8: 11-9.

7. Owen, O., 1946. Tomato nutrition, Sci Hortic. 9: 46-9.

8. Steel, R. G. D. and Torie, J. H., 1960. Principles and procedures of statistics with special reference to the biological sciences, McGraw Hill Book Company Inc. New York 409-11.

9. Stephen, D., 1969. Changes in yields and fertilizer responses with continuous cropping in Uganda, Exp. Agric. 5: 163-69.

10. Uzo, J. O., 1971. Effects of nitrogen, phosphorous and potassium on the yield of tomato (Lycopersicon esculentum Mills) in the tropics, Hort. Res. 11: 65-75. 